\title{
Maastricht University graduate surveys 2017
}

Citation for published version (APA):

Levels, M., \& Künn, A. (2017). Maastricht University graduate surveys 2017. ROA. ROA Fact Sheets No. $001 \mathrm{https}: / /$ doi.org/10.26481/umarof.2017001

Document status and date:

Published: 01/01/2017

DOI:

10.26481/umarof.2017001

Document Version:

Publisher's PDF, also known as Version of record

\section{Please check the document version of this publication:}

- A submitted manuscript is the version of the article upon submission and before peer-review. There can be important differences between the submitted version and the official published version of record.

People interested in the research are advised to contact the author for the final version of the publication, or visit the DOI to the publisher's website.

- The final author version and the galley proof are versions of the publication after peer review.

- The final published version features the final layout of the paper including the volume, issue and page numbers.

Link to publication

\footnotetext{
General rights rights.

- You may freely distribute the URL identifying the publication in the public portal. please follow below link for the End User Agreement:

www.umlib.nl/taverne-license

Take down policy

If you believe that this document breaches copyright please contact us at:

repository@maastrichtuniversity.nl

providing details and we will investigate your claim.
}

Copyright and moral rights for the publications made accessible in the public portal are retained by the authors and/or other copyright owners and it is a condition of accessing publications that users recognise and abide by the legal requirements associated with these

- Users may download and print one copy of any publication from the public portal for the purpose of private study or research.

- You may not further distribute the material or use it for any profit-making activity or commercial gain

If the publication is distributed under the terms of Article $25 \mathrm{fa}$ of the Dutch Copyright Act, indicated by the "Taverne" license above, 
Tuastricht University in Learning!

Research Centre for Education and the Labour Market | ROA

\section{Maastricht University graduate surveys 2017}

\section{ROA Fact Sheet}

ROA-F-2017/1

Researchcentrum voor Onderwijs en Arbeidsmarkt | ROA Research Centre For Education and the Labour Market / ROA 


\section{Maastricht University graduate surveys 2017}

To what degree does Maastricht University succeed in preparing its students for the labour market? What are the short and medium term career paths of Maastricht University alumni, and how do they look back on their study in Maastricht? In this factsheet, the most important results of a 2016 survey amongst three cohorts of Maastricht University alumni are presented. The first cohort graduated in the academic year 20I4-20I5 (I.5 years prior to the survey), the second cohort graduated in 20IO-20II ( 5 years prior to the survey) and the third cohort in the academic year 20052006 (Io years prior to the survey). ${ }^{1,2}$

\section{Position in the labour market}

Five to ten years after graduation, around $96 \%$ of the Maastricht University alumni have paid employment. Overall, approximately $4 \%$ of graduates in both cohorts reported to be out of the labour force. Important reasons for inactivity include participating in further education or taking care of children or relatives. A small percentage of graduates is looking for work. Table I gives a more detailed overview of graduates' unemployment rates - that is, the proportion of graduates who are currently not working but who are searching for work - by cohort and faculty. Overall, $7 \%$ of the 20I4-2015 cohort is currently unemployed, while this only applies to $2 \%$ of the $2010-201$ cohort and $2 \%$ of the 2005-2006 cohort. $^{3}$

In the 20I4-20I5 cohort, unemployment rates are highest among Law graduates. However, in the 20IO-20II cohort, unemployment rates are the highest among Psychology and Neuroscience graduates, while in the 2005-2006 cohort the highest rate is seen for Arts and Social Sciences graduates. ${ }^{4}$ We can conclude that labour market participation is higher for the 2010-20II and 2005-2006 cohorts of Maastricht University graduates, but is considerably lower for the 20I42015 cohort.

I Of the 20I4-20I5 cohort, 2778 respondents were approached, of whom $21 \%$ responded. For the 20IO-20II cohort, of the $245 \mathrm{I}$ alumni approached, $33 \%$ responded. Finally, for the 2005-2006 cohort, of the 2443 alumni that were approached, $36 \%$ responded.

2 The reader should keep in mind that the mix of studies offered by Maastricht University the respondents graduated from may vary between the three cohorts.

3 The unemployment rate might also vary within faculties. For example, in case of the Faculty of Health, Medicine and Life Sciences, the unemployment of Medical alumni is O\% I.5 years after graduation, whereas for Health and Life Sciences alumni the unemployment rate among the same cohort is $8 \%$.

4 It has to be noted that in the $2005-2006$ cohort too few cases from Humanities and Science were available for statistical analysis.
Table 1

Percentage of students who are unemployed

\begin{tabular}{|l|c|c|c|}
\hline & \multicolumn{3}{|c|}{ \% unemployed } \\
\hline Humanities and Sciences & $2014-2015$ & $2010-2011$ & $2005-2006$ \\
\hline Business and Economics & 5 & 0 & $\mathrm{X}$ \\
\hline Health, Medicine and Life Sciences & 5 & 1 & 2 \\
\hline Arts and Social Sciences & 6 & 2 & 2 \\
\hline Psychology and Neuroscience & 14 & 2 & 4 \\
\hline Law & 15 & 5 & 2 \\
\hline Maastricht University & 7 & 2 & 0 \\
\hline
\end{tabular}

$\mathrm{x}=$ too few cases

\section{Trends in unemployment}

To what extent has the recent economic crisis affected labour market opportunities of Maastricht University graduates since 2008? An indication can be found in the average unemployment rate of Maastricht University graduates, as reported by the surveys that were held between 2005 and 20I6. For twelve waves of the surveys, unemployment information of the three cohorts is available. For the two cohorts that have been on the labour market 5 or Io years, no visible trend in unemployment rates can be detected. Thus, the most recent economic crisis does not seem to have had an influence on the unemployment rate of Maastricht University alumni 5 to Io years into their labour market career. Nevertheless, a notable increase in unemployment rates can be observed for alumni one year after graduation, between 2007 and 2013 (see Figure I). However, since 20I4, the unemployment rate for alumni one year after graduation has been steadily decreasing again but remains above the pre-crisis level of unemployment. In Appendix A, yearly unemployment rates are reported per faculty.

5 Compared to preceding years, in 2015 and 2016 we use a slightly different definition of employment status in the surveys among alumni who graduated 5 and Io years prior to the survey. Whereas prior to 2015 a respondent had to report a working week of at least I2 hours to be considered as employed, from 2015 onwards the International Labour Organisation (ILO) definition applies, whereby all those who reported at least one hour of work are considered to be employed. In practice this makes little difference, since the vast majority of those employed are working fulltime, but it is possible that a small part of the change in unemployment in 2015 in those cohorts can be attributed to the definition change. 
Figure 1

Trends in unemployment ${ }^{1}$ one year after graduation

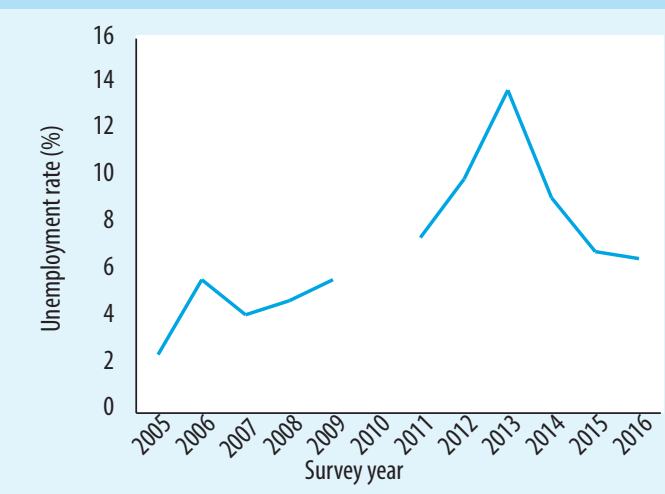

This survey was not administered in 2010

\section{Job characteristics}

It is important that graduates' education matches the requirements of their jobs well, since the match determines the extent to which they can actually use the knowledge and skills they have learned at university. ${ }^{6}$ Furthermore, the quality of the education-to-job match is known to be positively related to job satisfaction, career opportunities, and wages. An important indicator of the quality of the fit between education and the job is the vertical match (i.e., whether graduates are working in a job that requires an academic master's degree). Table 2 a shows the vertical match between graduates' current job and their level of education, for all three cohorts.

\section{Table 2a}

Percentage of students who have a vertical match

\begin{tabular}{|l|l|l|l|}
\hline \multicolumn{4}{|c|}{$\%$ working at university level or higher } \\
2014-2015 & $2010-2011$ & 2005-2006 \\
\hline
\end{tabular}

\begin{tabular}{|l|l|l|l|}
\hline Humanities and Sciences & 60 & 85 & $\mathrm{x}$ \\
\hline Business and Economics & 62 & 71 & 81 \\
\hline Health, Medicine and Life Sciences & 73 & 88 & 80 \\
\hline Arts and Social Sciences & 46 & 66 & 68 \\
\hline Psychology and Neuroscience & 80 & 83 & 87 \\
\hline Law & 60 & 79 & 81 \\
\hline Maastricht University & 67 & $\mathbf{7 8}$ & 80 \\
\hline
\end{tabular}

1 university level means at least a master degree from university (WO). $\mathrm{x}=$ too few cases

Table 2 a clearly shows that the vast majority of graduates succeed in finding a job at an appropriate level. However, the results of the vertical match are substantially different for the three cohorts. Among graduates from Maastricht University as a whole, the proportion of well-matched

6 See for example: R. van der Velden (20II), De effecten van betrouwbaarheid van onderwijsdiploma's op arbeidsproductiviteit: toepassing van een simulatiemodel, In: J.Dronkers (ed.), Goede bedoelingen in het onderwijs: Kansen en missers, boekaflevering Mens en Maatschappij, pp 27-49. respondents decreases from $80 \%$ for the oldest cohort to $67 \%$ for the youngest cohort. Although there are some fluctuations between the cohorts, in general we see lower proportions of well-matched graduates in the Faculty of Arts and Social Sciences, and relatively high proportions in the Faculty of Health, Medicine and Life Sciences and Faculty of Psychology and Neuroscience. ${ }^{7}$ The observation for Humanities and Science graduates in 20I4-20I5 is based on very small numbers, and so should be treated with caution.

Table $2 \mathrm{~b}$ presents numbers on the horizontal educationto-job match. This indicator measures the proportion of Maastricht University graduates who currently work in a job that requires their own or a related field of study. Again, it should be noted that most graduates succeed in finding a job in a field that well-matches their field of study. The three cohorts have different matching rates, with the results being most positive for the 20IO-20II cohort. Five years after graduation, $82 \%$ of the Maastricht University graduates are working in a job that matches well with their field of study, while I, 5 and Io years after graduation, respectively $72 \%$ and $75 \%$ of the Maastricht University graduates are working in their own or a related field of study. For these two cohorts, the underlying reasons for a horizontal mismatch might differ. Shortly after graduation, a horizontal mismatch is often related to labour market conditions not allowing graduates to find a job that matches the field of study, as well as voluntary choices preferring a job in a different field. Ten years after graduation, people have had a chance to make a career, and upward job mobility often comes with more 'generic' positions (such as managerial positions) not directly related to the initial field of study.

\section{Table $2 b$}

Percentage of students who have a horizontal match

\begin{tabular}{|l|c|c|c|}
\hline & \multicolumn{4}{|c|}{$\%$ working in own or related field of study } \\
\hline Humanities and Sciences & $2014-2015$ & $2010-2011$ & $2005-2006$ \\
\hline Business and Economics & 60 & 90 & X \\
\hline Health, Medicine and Life Sciences & 72 & 83 & 79 \\
\hline Arts and Social Sciences & 81 & 90 & 77 \\
\hline Psychology and Neuroscience & 49 & 68 & 46 \\
\hline Law & 71 & 77 & 75 \\
\hline Maastricht University & 70 & 79 & 76 \\
\hline
\end{tabular}

$x=$ too few cases

Next to differences between the three cohorts, we observe differences between the faculties. Overall, graduates from

7 For the Faculty of Health, Medicine and Life Sciences, a strong difference is again visible. Where medical students all find a university level job, graduates of the latter studies are less often vertically matched: in 55\% (2014-20I5), 82\% (20I0-20II), and 90\% (2005-2006) of the cases. 
the Faculty of Arts and Social Sciences show relatively low proportions of well-matched graduates. There is little systematic difference between the remaining faculties. Five years after graduating, alumni from the Faculty of Humanities and Sciences show relatively good horizontal match probabilities. Alumni from the Faculty of Health, Medicine and Life Sciences also are well-matched. It should be noted, however, that within the Faculty of Health, Medicine and Life Sciences, a strong distinction can be seen between the study of Medicine and the studies of Health and Life Sciences. Because of the very specific nature of their study, Medicine graduates show a considerably better horizontal match in all three cohorts (2014-20I5: 95\%, 20I0-2011: 98\%, 20052006: 95\%) than the graduates of Health and Life Science studies (20I4-20I5: 7I\%, 20IO-20II: 85\%, 2005-2006: 7I\%).

Table 3

Average monthly income and weekly working hours

\begin{tabular}{|l|c|c|c|r|r|r|}
\hline & \multicolumn{3}{|c|}{$\begin{array}{c}\text { gross income per month } \\
\text { (median) }\end{array}$} & \multicolumn{3}{c|}{ regular working hours } \\
& 2014 & 2010 & 2005 & 2014 & 2010 & 2005 \\
\hline & - & - & - & - & - & - \\
\hline Humanities and Sciences & 2015 & 2011 & 2006 & 2015 & 2011 & 2006 \\
\hline Business and Economics & 2.409 & $\mathrm{x}$ & $\mathrm{x}$ & 40 & 42 & $\mathrm{x}$ \\
\hline Health, Medicine and Life Sciences & 2.875 & 4.700 & 5.650 & 40 & 45 & 45 \\
\hline Arts and Social Sciences & 2.725 & 3.500 & 4.075 & 38 & 40 & 36 \\
\hline Psychology and Neuroscience & 1.925 & 2.780 & 3.725 & 38 & 40 & 39 \\
\hline Law & 2.105 & 2.800 & 3.300 & 36 & 40 & 32 \\
\hline Maastricht University & 2.510 & 3.600 & 4.600 & 40 & 40 & 38 \\
\hline
\end{tabular}

$\mathrm{x}=$ too few cases

\section{Income and working hours}

Table 3 shows the average monthly income of alumni and their average weekly working hours. Maastricht University alumni have a median income of $€ 2.550$ per month 1,5 years after graduation. This increases to $€ 3.7075$ years after graduation and to $€ 4.525$ Io years after graduation. Although the income patterns across disciplines slightly differ between the different survey years, Business and Economics graduates consistently show the highest monthly earnings and graduates from the Faculty of Arts and Social Sciences and the Faculty of Psychology and Neuroscience the lowest. ${ }^{8}$ It should be noted however that graduates of the faculty with top earners (Business and Economics) also report the highest average working hours.

8 The median income of Health, Medicine and Life Sciences graduates, is strongly influenced by the median income of the Health and Life Sciences studies. Medical graduates (a) have a higher starting salary and (b) are the best paid alumni Io years after graduation, with a median income of $€ 6.350$. Due to the structure of their career paths, Medical alumni also display the biggest income growth between five and ten years after graduation.

\section{International orientation of Maastricht University and its} graduates

It appears that the international orientation of Maastricht University and the fact that English is the main language of instruction in many study programmes continue to attract increasing numbers of international students for all faculties. It is interesting to see whether this international orientation is extended beyond the time of being a student at Maastricht University, in the form of high percentages of graduates working abroad. Table 4 shows per faculty the percentage of Maastricht University alumni of the various cohorts currently working inside and outside the Netherlands. For Maastricht University as a whole, 32\% of the alumni of 20I4-20I5 cohort is working abroad, while the same applies to $43 \%$ of the alumni of the 20IO-20II cohort and $27 \%$ of the alumni of the 2005-2006 cohort. These numbers include foreign students who returned to their home country after graduation.

To distinguish between international careers of alumni born in and outside the Netherlands, Appendix A includes Table 9. ${ }^{9}$ From this table, it becomes clear that the (32\%) alumni of the 2014-2015 cohort working abroad exists of $5 \%$ Dutch alumni, 20\% foreign alumni working in their country of origin and $7 \%$ foreign alumni working in a country outside the Netherlands which is not their country of birth. Table 9 moreover shows an explanation for the relative low percentage of alumni working abroad for the cohort 2005-2006. Of that cohort, $77 \%$ of the alumni in the dataset are Dutch, which is higher than in the 20I4-20I5 (65\%) and 20IO-20II (55\%) cohort. $^{\text {I }}$

Looking at all three cohorts, considerable variation exists between the faculties. Graduates of the Arts and Social Sciences and Humanities and Science Faculties are particularly internationally active, while for Law and especially Health, Medicine and Life Sciences graduates' international mobility is relatively rare. ${ }^{\text {II }}$

Table 9 (in Appendix A) shows that the group of alumni working in the Netherlands mainly consists of Dutch alumni. This holds for all cohorts and for all, but one, faculty: $23 \%$ of all alumni from the Faculty of Arts and Social Sciences are foreign born ánd work in the Netherlands I.5 years after graduation. This is exactly the same percentage as Dutch alumni working in the Netherlands. The Faculty of Psychology and Neuroscience is the faculty which has the highest percentage of foreign alumni working in the

9 Keep in mind that percentages are based on small numbers of observations.

IO Of the 20I4-20I5 cohort the response among foreign alumni is relatively low.

II It should be noted that these differences are closely related to the study programs offered. It is not so obvious for example that a medicine diploma from the UM can be used in another country than the Netherlands. 
Netherlands of the cohort 2005-2006. The faculties of Law and Humanities and Sciences 'lose' their Dutch students to the labour market of foreign countries the least.

The pattern of diminished mobility for the older cohorts can be seen in all faculties, despite the large differences in the absolute level of international mobility.

\section{Table 4}

Percentage of alumni working abroad

\begin{tabular}{|l|c|c|c|} 
& \multicolumn{3}{|c|}{ \% working abroad } \\
\hline Humanities and Sciences & $2014-2015$ & $2010-2011$ & $2005-2006$ \\
\hline Business and Economics & 70 & 70 & $x$ \\
\hline Health, Medicine and Life Sciences & 40 & 58 & 42 \\
\hline Arts and Social Sciences & 14 & 14 & 6 \\
\hline Psychology and Neuroscience & 55 & 70 & 51 \\
\hline Law & 44 & 53 & 20 \\
\hline Maastricht University & 41 & 34 & 12 \\
\hline
\end{tabular}

$x=$ too few cases

Maastricht University is geographically located in the Euregio Maas-Rijn (EMR). As such, it is interesting to see how many graduates remain in the EMR after graduation. Figure 2 presents these numbers for alumni 5 years after they graduate. The figure shows that alumni from the Faculty of Humanities and Science and the School of Business and Economics are relatively unlikely to be employed in the EMR. Alumni from the Faculty of Health, Medicine and Life Sciences are relatively likely to be employed in the Euregio Maas Rijn. Overall, it should be noted that most students do not work in the EMR five years after graduation. Only I $8 \%$ of all alumni work in the EMR.

\section{Figure 2}

Percentage of students working in the Euregio Maas-Rijn 5 years after graduation

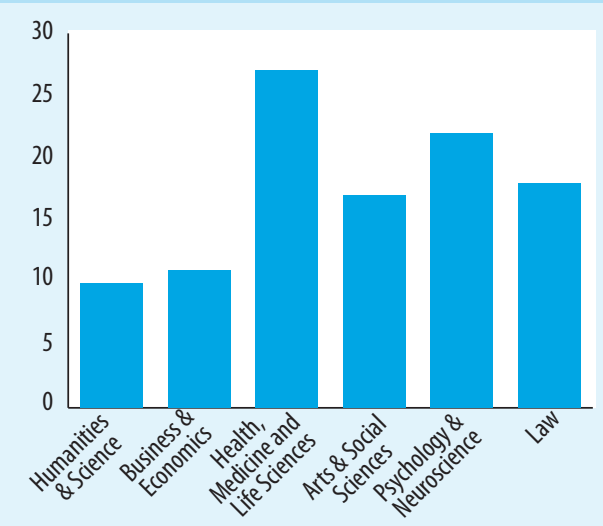

\section{International orientation, of jobs and alumni}

Graduates from the 2010-20II cohort were asked to report the extent to which they thought that their job offered the opportunity to work internationally, and whether they felt that international opportunities were important to them. We also asked whether they thought that the ability to work in an international environment was required in their current job. Table 5 shows the percentage of graduates who reported that these features applied to a high or very high extent to their current job, or to their personal preferences.

A little over half of all graduates reported that their jobs required the ability to function well in an international environment. Half of the graduates reported that the job was characterized by good opportunities to work internationally. The same proportion of alumni deems it important to work internationally.

Table 5

Percentage of respondents who reported that international opportunities were required in, applied to the current job, and were important to them

\begin{tabular}{|l|c|c|c|}
\hline $\begin{array}{l}\text { Required in } \\
\text { current job: } \\
\text { functioning in } \\
\text { international } \\
\text { context } \\
2010-2011\end{array}$ & $\begin{array}{c}\text { Apply to } \\
\text { current job: } \\
\text { opportunity } \\
\text { to work } \\
\text { internationally } \\
2010-2011\end{array}$ & $\begin{array}{c}\text { Important } \\
\text { to alumni: } \\
\text { opportunity } \\
\text { to work } \\
\text { internationally } \\
2010-2011\end{array}$ \\
\hline Humanities and Sciences & 77 & 62 & 65 \\
\hline Business and Economics & 72 & 63 & 67 \\
\hline Health, Medicine and Life Sciences & 31 & 34 & 33 \\
\hline Arts and Social Sciences & 66 & 52 & 69 \\
\hline Psychology and Neuroscience & 40 & 32 & 32 \\
\hline Law & 54 & 45 & 47 \\
\hline Maastricht University & 54 & 48 & 51 \\
\hline
\end{tabular}

${ }^{1-}$ to a high or very high degree

The differences between faculties are quite distinct. Graduates from the Faculty of Health, Medicine and Life Sciences and the Faculty of Psychology and Neuroscience are relatively unlikely to report that their jobs require international skills or provide them with international opportunities. Perhaps not coincidental, alumni from these faculties are also least likely to view international opportunities as being important.

It is interestingly to see the difference between these two faculties when it comes to international careers in Table 4. While $14 \%$ of the alumni from the Faculty of Health, Medicine and Life Sciences from cohort 20I0-20II do work abroad, for the Faculty of Psychology and Neuroscience this percentage is $53 \%$. So, combining Tables 3 and 4 , even though more than half of the graduates from the Faculty of Psychology and Neuroscience works abroad, their jobs do on average not require that much international skills, nor do they offer international opportunities. This suggests that working abroad does not necessarily require functioning in an international context, nor does it involve the opportunity to work internationally. This combination of 
a high percentage working abroad with a lower percentage of alumni mentioning international opportunities and international requirements in their jobs also holds for alumni from the Faculty of Arts and Social Sciences. On the other hand, the table also suggests that working in the Netherlands, does not mean that functioning in an international context is not required or that there are no opportunities to work internationally. This seems especially to be the case for alumni from the Faculty of Medicine, Health and Life Sciences and from the School of Business and Economics. Graduates from the School of Business and Economics, and the Faculty of Humanities and Science report relatively good international opportunities, and are most likely to report that their jobs require international skills.

\section{Satisfaction with Maastricht University's international orientation}

A considerable number of alumni work abroad, and a considerable number feels that working in an internationally oriented job is important to them. To what extent do alumni feel that the study programme at Maastricht University provided a good basis for a career in an international labour market? In total, $59 \%$ of the $2010-201$ and $49 \%$ of the 2005 2006 cohort responded that this applied to a high or very high extent (Table 6). The only faculty with a relatively low percentage of alumni feeling that their UM program offered a good basis for a career in an international labour market is the Faculty of Health, Medicine and Life Sciences. This is completely in line with the earlier shown percentages in Tables 4 and 5: Alumni from the Faculty of Health, Medicine and Life Sciences do on average work less often abroad and their jobs require and offer less international activities. There indeed seems to be a much smaller need to prepare students from the Faculty of Health, Medicine and Life Sciences for a career in an international labour market.

Graduates from the older cohort are generally less likely to assess that their study provided a good basis for an international career. This could indicate that graduates base their assessment on their own experiences, or alternatively, that the university as a whole has become better at preparing students for an international career. There may be support for this latter interpretation in the fact that graduates of the School of Business and Economics - with its established tradition of an internationally oriented education - are relatively positive about this aspect, and remain positive long after graduation.
Table 6

Percentage of alumni feeling that their UM program offered a good basis for a career in an international labour market

\begin{tabular}{|l|c|c|}
\hline Humanities and Sciences & $2010-2011$ & 2005-2006 \\
\hline Business and Economics & 73 & $\mathrm{x}$ \\
\hline Health, Medicine and Life Sciences & 81 & 74 \\
\hline Arts and Social Sciences & 38 & 24 \\
\hline Psychology and Neuroscience & 57 & 48 \\
\hline Law & 50 & 35 \\
\hline Maastricht University & 53 & 49 \\
\hline
\end{tabular}

$x=$ too few cases

\section{Satisfaction with Maastricht University in general}

Finally, alumni were asked how they looked back on their study at Maastricht University and to assess what choices they would make in retrospect. With the benefit of hindsight, would graduates choose the same study at the same university again? In the 20I4-20I5 cohort, $76 \%$ of the alumni would again choose the exact same study at Maastricht University. For the cohorts that graduated in 2010-20II and 2005-2006, these figures were $77 \%$ and $73 \%$, respectively. Table 7 presents the survey results for the three cohorts per faculty. Differences across faculties are small.

\section{Table 7}

Percentage of alumni who would again choose the exact same study at Maastricht University

\begin{tabular}{|l|c|c|c|}
\hline & $2014-2015$ & $2010-2011$ & $2005-2006$ \\
\hline Humanities and Sciences & 82 & 71 & $\mathrm{x}$ \\
\hline Business and Economics & 79 & 80 & 76 \\
\hline Health, Medicine and Life Sciences & 79 & 74 & 73 \\
\hline Arts and Social Sciences & 69 & 69 & 69 \\
\hline Psychology and Neuroscience & 67 & 80 & 62 \\
\hline Law & 75 & 80 & 77 \\
\hline Maastricht University & 76 & 77 & 73 \\
\hline
\end{tabular}

$\mathrm{x}=$ too few cases 


\section{Appendix A}

Table 8

Unemployment ${ }^{1,2}$

\begin{tabular}{|c|c|c|c|c|c|c|c|c|c|}
\hline & 2009 & 2010 & 2011 & 2012 & 2013 & 2014 & & 2015 & 2016 \\
\hline & $\mathrm{T}+1$ & $\mathrm{~T}+1$ & $\mathrm{~T}+1$ & $\mathrm{~T}+1$ & $\mathrm{~T}+1$ & $\mathrm{~T}+1$ & & $\mathrm{~T}+1$ & $\mathrm{~T}+1$ \\
\hline & $2007-2008$ & 2008-2009 & 2009-2010 & 2010-2011 & 2011-2012 & $2012-2013$ & & 2013-2014 & 2014-2015 \\
\hline Business and Economics & 5.7 & - & 4.9 & 6 & 6.3 & 5.7 & & 3.6 & 0.0 \\
\hline Health and Life Sciences & 0 & - & 4.4 & 8.3 & 16.4 & 10.3 & & 9.2 & 8.0 \\
\hline Medicine & 0 & - & 0 & 1.7 & 2.5 & 3.3 & & 2.7 & 0.0 \\
\hline Arts and Social Sciences & 18.5 & - & 23.9 & 25.5 & 33.3 & 13.7 & & 5.9 & 5.6 \\
\hline Psychology and Neuroscience & 6.1 & - & 11.4 & 16.7 & 25.6 & 7.6 & & 10.3 & 14.1 \\
\hline Law & 6 & - & 8.8 & 7.1 & 14.3 & 16.2 & & 10.3 & 14.6 \\
\hline \multirow[t]{4}{*}{ Maastricht University } & 5.7 & - & 7.5 & 10 & 13.8 & 9.2 & & 6.9 & 6.6 \\
\hline & 2009 & 2010 & 2011 & 2012 & 2013 & 2014 & 2015 spring & 2015 fall & 2016 \\
\hline & $\mathrm{T}+5$ & $T+5$ & $\mathrm{~T}+5$ & $\mathrm{~T}+5$ & $\mathrm{~T}+5$ & $\mathrm{~T}+5$ & $\mathrm{~T}+5$ & $\mathrm{~T}+5$ & $\mathrm{~T}+5$ \\
\hline & $2002-2003$ & 2003-2004 & $2004-2005$ & $2005-2006$ & $2006-2007$ & $2007-2008$ & $2008-2009$ & $2009-2010$ & 2010-2011 \\
\hline Business and Economics & 3.2 & 2.2 & 5.4 & 1.9 & 0 & 0 & 0.9 & 1.5 & 1.3 \\
\hline Health and Life Sciences & 2.4 & 1.7 & 2.7 & 2.1 & 3.1 & 3.5 & 4.3 & 5.3 & 3.3 \\
\hline Medicine & 0 & 0 & 1.5 & 0 & 0 & 1.3 & 0.0 & 4.9 & 0 \\
\hline Arts and Social Sciences & $x$ & $x$ & 3.8 & 10.1 & 5.7 & 4.8 & 4.4 & 6.7 & 1.5 \\
\hline Psychology and Neuroscience & 1.9 & 7 & 10.3 & 4.2 & 0 & 4.3 & 7.5 & 2.5 & 4.9 \\
\hline Law & 1.2 & 4.3 & 5 & 0 & 6.8 & 3.8 & 2.6 & 1.8 & 0 \\
\hline \multirow[t]{4}{*}{ Maastricht University } & 2.3 & 2.5 & 4.4 & 2.7 & 3.2 & 2.6 & 2.6 & 3.4 & 1.5 \\
\hline & 2009 & 2010 & 2011 & 2012 & 2013 & 2014 & 2015 spring & 2015 fall & 2016 \\
\hline & $\mathrm{T}+10$ & $\mathrm{~T}+10$ & $\mathrm{~T}+10$ & $\mathrm{~T}+10$ & $\mathrm{~T}+10$ & $\mathrm{~T}+10$ & $\mathrm{~T}+10$ & $\mathrm{~T}+10$ & $\mathrm{~T}+10$ \\
\hline & 1997-1998 & 1998-1999 & $1999-2000$ & $2000-2001$ & $2001-2002$ & $2002-2003$ & $2003-2004$ & $2004-2005$ & $2005-2006$ \\
\hline Business and Economics & 0 & 3 & 2.8 & 0.9 & 0.9 & 0.7 & 1.0 & 0 & 1.6 \\
\hline Health and Life Sciences & 0.6 & 0.6 & 2 & 1.2 & 3.1 & 3.7 & 0.6 & 2.6 & 1.6 \\
\hline Medicine & 0 & 0 & 2.6 & 1.8 & 0 & 2 & 3.6 & 1.5 & 1.2 \\
\hline Arts and Social Sciences & $x$ & $x$ & $x$ & $x$ & $x$ & $x$ & 4.3 & 11.5 & 4.4 \\
\hline Psychology and Neuroscience & 0 & 0 & 0 & 3.8 & 0 & 4.9 & 2.0 & 3.1 & 1.7 \\
\hline Law & 0 & 1.5 & 0 & 6.1 & 1.6 & 0 & 1.4 & 0 & 0 \\
\hline Maastricht University & 0.3 & 1.7 & 2 & 2 & 2 & 2.1 & 1.5 & 3 & 1.7 \\
\hline
\end{tabular}

1 too little information on the Faculty of Humanities and Sciences.

2 It should be noted that a slightly different definition of employment status was used in the T+5 and T+10 surveys in 2015 and 2016 than in the preceding years. Whereas prior to 2015 a respondent had to report a working week of at least 12 hours to be considered as employed, from 2015 onwards the International Labour Organisation (ILO) definition applies, whereby all those who reported at least one hour of work are considered to be employed. In practice this makes little difference, since the vast majority of those employed are working fulltime, but it is possible that a small part of the change in unemployment in 2015 in those cohorts can be attributed to the definition change.

$\mathrm{x}=$ too few cases 
Table 9

International careers of alumni born in and outside the Netherlands, $\mathbf{s}^{1,2}$

\begin{tabular}{|c|c|c|c|c|c|c|}
\hline $\begin{array}{c}\text { 2014-2015 } \\
\text { Faculty }\end{array}$ & $\begin{array}{l}\text { Born in NL } \\
\text { Work in NL }\end{array}$ & $\begin{array}{c}\text { Born in NL } \\
\text { Work outside NL }\end{array}$ & $\begin{array}{c}\text { Born outside NL } \\
\text { Work in NL }\end{array}$ & $\begin{array}{l}\text { Born outside NL } \\
\text { Work in country of birth }\end{array}$ & $\begin{array}{c}\text { Born outside NL } \\
\text { Work in a third country* }\end{array}$ & $\mathrm{N}$ \\
\hline Business and Economics & $53 \%$ & $7 \%$ & $7 \%$ & $22 \%$ & $11 \%$ & 105 \\
\hline Health, Medine and Life Sciences & $82 \%$ & $3 \%$ & $5 \%$ & $9 \%$ & $1 \%$ & 214 \\
\hline Arts and Social Sciences & $23 \%$ & $11 \%$ & $23 \%$ & $28 \%$ & $15 \%$ & 53 \\
\hline Humanities and Sciences & $15 \%$ & $10 \%$ & $15 \%$ & $45 \%$ & $15 \%$ & 20 \\
\hline Psychology and Neuroscience & $47 \%$ & $7 \%$ & $9 \%$ & $27 \%$ & $9 \%$ & 55 \\
\hline Law & $56 \%$ & $4 \%$ & $3 \%$ & $27 \%$ & $10 \%$ & 71 \\
\hline Maastricht University & $60 \%$ & $5 \%$ & $8 \%$ & $20 \%$ & $7 \%$ & 518 \\
\hline $2010-2011$ & Born in NL & Born in NL & Born outside NL & Born outside NL & Born outside NL & $\mathrm{N}$ \\
\hline Faculty & Work in NL & Work outside NL & Work in NL & Work in country of birth & Work in a third country* & \\
\hline Business and Economics & $35 \%$ & $6 \%$ & $6 \%$ & $41 \%$ & $12 \%$ & 217 \\
\hline Health, Medicine and Life Sciences & $77 \%$ & $4 \%$ & $8 \%$ & $8 \%$ & $3 \%$ & 179 \\
\hline Arts and Social Sciences & $24 \%$ & $3 \%$ & $7 \%$ & $49 \%$ & $17 \%$ & 59 \\
\hline Psychology and Neuroscience & $36 \%$ & $4 \%$ & $6 \%$ & $43 \%$ & $11 \%$ & 53 \\
\hline Law & $64 \%$ & $2 \%$ & $3 \%$ & $21 \%$ & $10 \%$ & 120 \\
\hline Maastricht University & $51 \%$ & $4 \%$ & $6 \%$ & $29 \%$ & $10 \%$ & 648 \\
\hline $2005-2006$ & Born in NL & Born in NL & Born outside NL & Born outside NL & Born outside NL & $\mathrm{N}$ \\
\hline Faculty & Work in NL & Work outside NL & Work in NL & Work in country of birth & Work in a third country* & \\
\hline Business and Economics & $55 \%$ & $9 \%$ & $3 \%$ & $20 \%$ & $12 \%$ & 294 \\
\hline Health, Medine and Life Sciences & $91 \%$ & $3 \%$ & $4 \%$ & $1 \%$ & $1 \%$ & 247 \\
\hline Arts and Social Sciences & $49 \%$ & $8 \%$ & $3 \%$ & $25 \%$ & $15 \%$ & 75 \\
\hline Psychology and Neuroscience & $67 \%$ & $9 \%$ & $11 \%$ & $13 \%$ & $0 \%$ & 55 \\
\hline Law & $82 \%$ & $7 \%$ & $6 \%$ & $4 \%$ & $1 \%$ & 72 \\
\hline Maastricht University & $70 \%$ & $7 \%$ & $4 \%$ & $12 \%$ & $7 \%$ & 748 \\
\hline
\end{tabular}

1 Too little information on the Faculty of Humanities and Sciences in the cohorts 2010-2011 and 2005-2006.

2 Information about country of birth is not known for complete sample, therefore the percentage working abroad might differ between Table 9 (where country of birth is required) and Table 4 (where country of birth is not needed).

* Third country stands for another country than Netherlands or country of birth. 


\section{Imprint}

(C) 2017. Research Centre for Education and the Labour Market (ROA). Nothing in this publication may be duplicated in any way without prior written permission from ROA's director.

Research Centre for Education and the Labour Market Maastricht University

School of Business and Economics

secretary-roa-sbe@maastrichtuniversity.nl

www.roa.nl

\section{Layout}

ROA Secretariat, Maastricht

September 2017 
Researchcentrum voor Onderwijs en Arbeidsmarkt

Postbus 616

6200 MD Maastricht

$\mathrm{T}+31433883647$

F +31 433884914

secretary-roa-sbe@maastrichtuniversity.nl

www.roa.nl

Maastricht University

School of Business and Economics 